Gut, 1983, 24, 724-733

\title{
Peptide-containing nerve fibres in the gut wall in Crohn's disease
}

\author{
K SJÖLUND, O B SCHAFFALITZKY DE MUCKADELL, J FAHRENKRUG, \\ R HÅKANSON, B G PETERSON, AND F SUNDLER
}

From the Departments of Internal Medicine, Pharmacology, Surgery, and Histology, University of Lund, Lund, Sweden, and Medical Department P2, Rigshospitalet and Department of Clinical Chemistry, Bispebjerg Hospital. Copenhagen, Denmark

SUMmary Neurones containing VIP, substance $P$, or enkephalin were studied by immunocytochemistry in intestinal specimens from 27 patients with Crohn's disease. Also several endocrine cell systems in the gut were examined. The results were compared with those from a control group of 26 patients. The relative frequency of various endocrine cells did not differ overtly from that in controls. Vasoactive intestinal polypeptide and substance P nerve fibres were distributed in all layers of the gut wall, including the submucosal and myenteric plexuses, whereas enkephalin fibres were. restricted to the smooth muscle layer and the myenteric plexus. The distribution and frequency of the peptide-containing nerve fibres were the same in Crohn's disease patients as in control patients. A proportion of these nerve fibres, however, were notably coarse in the Crohn's disease patients. This was particularly apparent in the afflicted parts of the intestine although it was noted also in non-afflicted parts. The concentration of VIP and substance $P$ (expressed as pmol/g wet weight) did not, however, exceed that of the control group.

Crohn's disease is a chronic form of intestinal inflammation which is segmental, transmural, and granulomatous. ${ }^{1}$ The lesions are predominantly localised to the distal ileum but may engage any part of the gastrointestinal tract. ${ }^{2}$ As the disease progresses fibrosis develops, causing mural thickening. Stenoses often develop, requiring surgery. ${ }^{3}$ Pathologists have observed conspicuously coarse intramural nerve fibres both in the submucosal layer and in the smooth muscle ${ }^{45}$ and recently Bishop et $a t^{6}$ in a study of patients with Crohn's disease predominantly localised to the colon reported that nerve fibres containing vasoactive intestinal polypeptide were included among the coarse fibres, and that the VIP concentration in the afflicted parts of the intestine was markedly raised.

In the present study of Crohn's disease patients, most of which had lesions in the ileum, we have examined a variety of intestinal endocrine cell systems and the neuronal systems containing VIP, substance $P$, or enkephalin. The immunocyto-

Address for correspondence: Dr Rolf Håkanson, Farmakologiska Institutionen, Sölvegatan 10, S-223 62 Lund, Sweden.

Received for publication 22 October 1982
Table 1 Origin of resected specimens in patients with Crohn's disease and in the control group

\begin{tabular}{|c|c|c|c|c|c|c|}
\hline \multirow{3}{*}{$\begin{array}{l}\text { Category } \\
\text { of patients }\end{array}$} & \multirow{3}{*}{$\begin{array}{l}\text { Total } \\
\text { number }\end{array}$} & \multicolumn{5}{|c|}{ Origin of specimens } \\
\hline & & \multicolumn{2}{|c|}{ Ileum } & \multicolumn{3}{|l|}{ Colon } \\
\hline & & $m$ & $d$ & $p$ & $m$ & $d$ \\
\hline \multirow{2}{*}{$\begin{array}{l}\text { Crohn's } \\
\text { disease } \\
\text { Control } \\
\text { patients }\end{array}$} & $27^{*}$ & $6(6)$ & $15(14)$ & $12(6)$ & $4(2)$ & $6(5)$ \\
\hline & $26 \dagger$ & 1 & 12 & 10 & 1 & 7 \\
\hline
\end{tabular}

* Nine had had previous intestinal resections; six with ileocaecal resection, two with resection of the ileum and distal colon, and one with resection of the distal colon.

† Twenty-one patients had carcinoma coli (without signs of inflammatory bowel disease), four had ulcerative colitis (specimens were taken from the ileum only). One patient was subjected to intestinal resection because of suspected tumour. The patients with ulcerative colitis were treated surgically because of suspected malignancy or because of unsuccessful medical treatment. Most lesions were localised to the distal colon leaving colon ascendens unaffected.

Ileum: $\mathrm{m}=$ middle $(30-50 \mathrm{~cm}$ from the ileocaecal valve), $\mathrm{d}=$ distal (within $30 \mathrm{~cm}$ from the ileocaecal valve).

Colon: $\mathrm{p}=$ proximal (colon ascendens), $\mathrm{m}=$ middle (colon transversum), $\mathrm{d}=$ distal (colon sigmoideum).

Number in parentheses indicates number of patients with lesions in the location specified. 
Table 2 Details of the patients undergoing intestinal resection because of Crohn's disease

\begin{tabular}{|c|c|c|c|c|c|c|c|c|c|c|c|}
\hline \multirow{4}{*}{$\begin{array}{l}\text { Site of } \\
\text { lesions }\end{array}$} & \multirow{4}{*}{$\begin{array}{l}\text { Number } \\
\text { of } \\
\text { patients }\end{array}$} & \multicolumn{6}{|c|}{ Number of patients with } & \multirow{2}{*}{\multicolumn{4}{|c|}{ Number of patients on treatment with }} \\
\hline & & \multirow{3}{*}{$\begin{array}{l}\text { High sedi- } \\
\text { mentation } \\
\text { rate and/or } \\
\text { orosomucoid } \\
\text { plasma } \\
\text { concentration }\end{array}$} & \multirow{3}{*}{$\begin{array}{l}\text { Trans- } \\
\text { mural } \\
\text { inflam- } \\
\text { mation }\end{array}$} & \multirow[b]{3}{*}{ Fistulas } & \multirow{2}{*}{\multicolumn{3}{|c|}{ Intestinal obstruction }} & & & & \\
\hline & & & & & & & & \multirow[b]{2}{*}{ Steroids } & \multirow{2}{*}{$\begin{array}{l}\text { Sulpha- } \\
\text { salazine }\end{array}$} & \multirow{2}{*}{$\begin{array}{l}\text { Metro- } \\
\text { nidazole }\end{array}$} & \multirow{2}{*}{$\begin{array}{l}\text { No } \\
\text { treat- } \\
\text { ment }\end{array}$} \\
\hline & & & & & Severe & Moderate & Slight & & & & \\
\hline Ileum & 20 & 17 & 18 & 7 & 9 & 8 & 3 & 2 & 3 & 5 & 12 \\
\hline Colon & 13 & 12 & 7 & 2 & 2 & 4 & 7 & 5 & 3 & 5 & 2 \\
\hline
\end{tabular}

chemical findings have been correlated to the results of radioimmunoassay of VIP and substance $P$.

\section{Methods}

\section{TISSUE MATERIAL}

Fresh specimens were taken during surgery from 27 patients with Crohn's disease (14 women and 13 men, median age 31 years, range 18-72 years) (Table 1). All patients except four displayed signs of active intestinal inflammation (high sedimentation rate and/or increased orosomucoid plasma concentration ${ }^{7}$ ). For details on the patients see Table 2 . Specimens were collected from afflicted segments and adjoining macroscopically non-afflicted segments. The inflammatory changes were assessed also by histological examination (see section on Histology and Histochemistry). Macroscopically afflicted tissue specimens exhibited marked inflammatory changes (infiltration of the stromal connective tissue by inflammatory cells, thickening of the lamina propria and submucosa, at times loss of epithelium), whereas non-afflicted tissue specimens displayed no, or slight, inflammatory changes (focal infiltration of inflammatory cells). At least five specimens were taken from each location in each patient.

For comparison, fresh surgical specimens were taken from 26 patients without intestinal inflammation (13 women and 13 men, median age 56 years, range 22-86 years) (Table 1). Most of these patients were operated on because of carcinoma of the colon. The tissue specimens were collected from the resected tissues as far away as possible from the afflicted part.

Whole wall specimens were taken for conventional histology and immunocytochemistry. For chemical determinations the specimens were divided in mucosa + submucosa and smooth muscle. Care was taken to separate the mucosa + submucosa from the muscle layers by means of a small pair of scissors. The completeness of the dissection was verified by microscopic analysis of random specimens. Invariably, the contamination of the muscle with submucosa was minor.

\section{HISTOLOGY AND HISTOCHEMISTRY}

Fresh specimens were immediately frozen to the temperature of liquid nitrogen in a propane/ propylene mixture and freeze dried. They were then exposed to gaseous diethylpyrocarbonate ${ }^{8}$ or formaldehyde ${ }^{9}$ and embedded in paraffin wax in vacuo. Sections were cut at $5 \mu \mathrm{m}$ thickness and placed on albumin coated glass slides. For conventional histology sections were stained with haematoxylineosin and mounted in Permount ${ }^{\circledR}$. For immunocytochemistry (the PAP technique of Sternberger ${ }^{10}$ ) the sections were deparaffinised in xylene, hydrated and exposed to peptide or 5-hydroxytryptamine antiserum (Table 3) for 24 hours at $4^{\circ} \mathrm{C}$. After rinsing in phosphate buffer, the sections were incubated with unlabelled goat-anti-rabbit IgG (SBL, Stockholm, Sweden) (diluted 1:30) for 30 minutes at room temperature followed by incubation with peroxidase-anti-peroxidase (PAP) complex (diluted 1:160). PAP complex was purchased from Cappel Laboratories, Downington, Pennsylvania, USA. The sections were dehydrated, mounted in Permount ${ }^{\circledR}$ and examined by light microscopy. This protocol can be used to show peptides in endocrine cells. For demonstration of peptides in nerve fibres the specimens were quickly immersed in ice-cold $4 \%$ buffered formaldehyde solution ( $\mathrm{pH} 7 \cdot 2)$. After fixation overnight the specimens were rinsed repeatedly in buffer containing 5\% sucrose, frozen and sectioned at 15 $\mu \mathrm{m}$ thickness in a cryostat, and processed for the immunocytochemical demonstration of VIP, substance $P$, and leu-enkephalin using the indirect immunofluorescence technique. ${ }^{11}$ Details of the antisera are given in Table 3. The sections were exposed to peptide antiserum for three hours at room temperature. After thorough rinsing in phosphate buffer they were incubated with 
Table 3 Characteristics of antisera used for immunocytochemistry

\begin{tabular}{|c|c|c|c|c|c|c|}
\hline \multirow[b]{2}{*}{ Antigen } & \multirow[b]{2}{*}{ Code no } & \multirow[b]{2}{*}{$\begin{array}{l}\text { Directed } \\
\text { against }\end{array}$} & \multicolumn{2}{|c|}{ Working dilution } & \multirow[b]{2}{*}{ Source } & \multirow[b]{2}{*}{$\begin{array}{l}\text { Refer- } \\
\text { ence }\end{array}$} \\
\hline & & & $\begin{array}{l}\text { Immuno- } \\
\text { fluores- } \\
\text { cence }\end{array}$ & $\begin{array}{l}\text { PAP- } \\
\text { staining }\end{array}$ & & \\
\hline 1 Gastrin & 4562 & $\begin{array}{l}\text { C-terminal } \\
\text { tetrapeptide }\end{array}$ & - & $1: 10240$ & $\begin{array}{l}\text { J Rehfeld, Copenhagen, } \\
\text { Denmark }\end{array}$ & 17 \\
\hline 2 Glucagon & 7811 & Middle part & - & $1: 640$ & Milab, Malmö, Sweden & 18 \\
\hline 3 Leu-enkephalin & Leu-enk & - & $1: 80$ & $1: 240$ & $\begin{array}{l}\text { K J Chang and R Miller; } \\
\text { Burroughs Wellcome } \\
\text { Res Lab, USA }\end{array}$ & 19 \\
\hline 4 Neurotensin & HC-8 & $\begin{array}{l}\text { C-terminal } \\
\text { hexapeptide }\end{array}$ & - & $1: 640$ & R Carraway, Boston, Mass, USA & 20 \\
\hline $\begin{array}{l}5 \text { Somatostatin } \\
6 \text { Substance P } \\
7 \text { VIP } \\
8 \text { 5-Hydroxy- } \\
\text { tryptamine }\end{array}$ & $\begin{array}{l}19578 \\
\text { SP } 8 \\
7852 \\
\text { N-Ser-2 }\end{array}$ & $\begin{array}{l}\bar{C} \text {-terminus } \\
- \\
-\end{array}$ & $\begin{array}{l}- \\
1: 80 \\
1: 160 \\
-\end{array}$ & $\begin{array}{l}1: 2560 \\
1: 320 \\
1: 5120 \\
1: 800\end{array}$ & $\begin{array}{l}\text { M P Dubois, Nouzilly, France } \\
\text { P C Emson, Cambridge, England } \\
\text { Milab, Malmö, Sweden } \\
\text { Immunonuclear, Stillwater, } \\
\text { Minn, USA }\end{array}$ & $\begin{array}{l}21 \\
22 \\
23 \\
24\end{array}$ \\
\hline
\end{tabular}

fluorescein-labelled anti-rabbit IgG for 30 minutes at room temperature. After another rinsing in phosphate buffer the sections were mounted in phosphate buffered glycerin and examined in a fluorescence microscope. All solutions contained $0.25 \%$ serum albumin and $0.25 \%$ Triton X-100. Controls in the immunocytochemical procedure were run as recommended by Sternberger ${ }^{10}$ and included incubation of sections with peptide or 5-hydroxytryptamine antiserum, inactivated by addition of antigen in excess (1-100 $\mu \mathrm{g}$ synthetic peptide or $100 \mu \mathrm{g}$ amine per millilitre diluted antiserum).

\section{CELL COUNTING AND QUANTITATION AND EVALUATION OF NERVE FIBRES}

The endocrine cells were counted per visual field $(1.4 \mathrm{~mm}$ in diameter) in at least five to 10 sections (two visual fields/section) cut perpendicular to the mucosal surface so that the whole of the mucosa was visible. Only cells with visible nuclei were counted. The cell number was expressed per unit length of sectioned mucosa $(1.4 \mathrm{~mm})$. Consecutive sections were discarded to avoid repeated counting of the same cells. Cells were not counted in severely afflicted mucosa where many crypts were lost owing to ulcers. Peptide-containing nerve fibres were studied in cryostat sections. Sections of four to eight specimens from each patient were examined and the peptide-containing nerve fibres were classified as to their frequency and morphology. They were graded semi-quantitatively (subjectively) by one and the same individual in three categories: rare, moderate in number, numerous, and delicate, medium and coarse, respectively. Delicate fibres are those exhibiting a typical varicose appearance. Coarse fibres display thickening of the intervaricose parts. Newly cut sections from the same specimens were evaluated blindly on three to five separate occasions.

\section{RADIOIMMUNOASSAY}

Fresh tissue material was immediately frozen, weighed, minced, and homogenised in acidified ethanol (70\% ethanol containing $0.74 \%$ hydrochloric acid). Solids were removed by centrifugation and the supernatants were decanted and dried under a gentle stream of air. Samples were reconstituted in $0 \cdot 04 \mathrm{M}$ sodium phosphate buffer $(\mathrm{pH} \mathrm{7.4)}$ containing $100 \mathrm{mmol}$ sodium chloride. Protein was measured by the method of Lowry et al. ${ }^{12}$ Two volumes of $0.04 \mathrm{M}$ sodium phosphate buffer containing 100 mmol sodium chloride and $45 \mu \mathrm{m}$ human serum albumin were added and substance $P$ and VIP were measured by radioimmunoassay. Each sample was assayed in duplicate in three dilutions.

\section{SUBSTANCE $P$}

Antiserum K $16^{13}$ was generously donated by $\mathrm{Dr} G$ Nilsson, Karolinska Institute, Stockholm, Sweden. 8-Tyr-SP (Peninsula, Calif, USA) was iodinated by a chloramine-T method ${ }^{14}$ and the ${ }^{125}$ I-labelled tracer 
Table 4 Number of various intestinal endocrine cells per unit length of sectioned mucosa in patients with Crohn's disease (CD) and in control patients

\begin{tabular}{|c|c|c|c|c|c|c|}
\hline \multirow[b]{3}{*}{ Cell type } & \multicolumn{3}{|l|}{ Ileum } & \multicolumn{3}{|l|}{ Colon } \\
\hline & \multirow[b]{2}{*}{ Controls } & \multicolumn{2}{|l|}{$C D$} & \multirow[b]{2}{*}{ Controls } & \multicolumn{2}{|l|}{$C D$} \\
\hline & & $\boldsymbol{A}$ & $: \quad N A$ & & $\boldsymbol{A}$ & $N A$ \\
\hline Gastrin/CCK* & $6 \pm 2$ & $9 \pm 2$ & $8 \pm 3$ & - & - & - \\
\hline Glucagon/glicentin $†$ & $23 \pm 2$ & $19 \pm 2$ & $26 \pm 3$ & $14 \pm 2$ & $17 \pm 3$ & $12 \pm 2$ \\
\hline Neurotensin & $13 \pm 2$ & $9 \pm 2$ & $11 \pm 2$ & - & - & - \\
\hline Somatostatin & $4 \pm 0$ & $7 \pm 1$ & $5 \pm 1$ & $3 \pm 0$ & $4 \pm 1$ & $4 \pm 1$ \\
\hline Substance $P$ & $6 \pm 1$ & $4 \pm 1$ & $6 \pm 1$ & - & - & - \\
\hline 5-Hydroxytryptamine & $26 \pm 2$ & $24 \pm 3$ & $32 \pm 3$ & $23 \pm 2$ & $21 \pm 2$ & $22 \pm 4$ \\
\hline
\end{tabular}

Mean \pm SE. $A=$ afflicted mucosa; NA = non-afflicted mucosa.

* Antiserum 4562 recognises both gastrin and CCK. The number of cells shown with this antiserum greatly exceeds the sum of cells shown with gastrin-specific and CCK-specific antisera (Sjölund et al 1982). Gastrin cells were absent from the ileum and CCK cells were extremely rare $(<1 /$ visual field). The cells shown by antiserum 4562 are referred to as gastrin/CCK cells, although the majority of these cells contain neither gastrin nor CCK.

† Antiserum 7811 recognises both glucagon and glicentin. Hence, the cells shown may be either glucagon cells or glicentin cells.

was purified by gel chromatography on a Sephadex G25 SF column $(500 \times 10 \mathrm{~mm})$. Acetic acid $(0 \cdot 2 \mathrm{M})$ containing $75 \mu \mathrm{m}$ human serum albumin was used as eluant. These procedures were carried out at room temperature. Samples $(200 \mu \mathrm{l})$, buffer $(200 \mu \mathrm{l})$, and antiserum $(200 \mu \mathrm{l}, 1: 64000)$ were incubated at $4^{\circ} \mathrm{C}$ for 72 hours after which ${ }^{125}$ I-labelled substance $P$ $(100 \mu \mathrm{l}, 3000 \mathrm{cpm})$ was added. Separation of free from antibody bound tracer was carried out after further 48 hours incubation using charcoal coated with human plasma. Recovery of authentic substance $P$ (Peninsula) was $70 \%$.

Cross reactivity with cholecystokinin-8, leu- and met-enkephalin, gastrin-4, gastrin-17, glucagon, motilin, neurotensin, somatostatin, and VIP was less than $0.03 \%$, with bombesin it was $0.14 \%$ (concentration of peptides: $75 \mathrm{nM}$ ). Binding of iodinated 8-Tyr-SP decreased from 100 to $76 \%$ after addition of $7.5 \mathrm{pM}$ substance $\mathrm{P}$. At $150 \mathrm{pmol}$ substance $P$ the between-assay variation was $10 \%$. Upon gel chromatography the antiserum detected only one molecular form of substance $P$ in extracts of human intestine (see also Brodin et $a^{15}$ ). The concentration of substance $P$ was expressed as pmol/gram wet weight or per gram extracted protein.

VIP

Antiserum 5603-6 was used. Radioimmunoassay was carried out as previously described. ${ }^{16}$ Concentrations of VIP were expressed as pmol/gram wet weight or per gram extracted protein.

\section{STATISTICS}

Statistical analysis of the difference in number of intestinal endocrine cells between patients with

Table 5 Semiquantitative assessment of the number of nerve fibres containing vasoactive intestinal polypeptide (VIP), substance $P(S P)$, or enkephalin (Enk) in the intestinal wall of patients with Crohn's disease (CD) and control patients

\begin{tabular}{|c|c|c|c|c|c|c|c|c|c|c|c|c|}
\hline \multirow{3}{*}{$\begin{array}{l}\text { Nerve } \\
\text { fibres } \\
\text { containing }\end{array}$} & \multicolumn{6}{|c|}{ Ileum } & \multicolumn{6}{|c|}{ Colon } \\
\hline & \multicolumn{2}{|c|}{$\begin{array}{l}\text { Mucosat } \\
\text { submucosat } \\
\text { submucosal } \\
\text { plexus }\end{array}$} & \multicolumn{2}{|c|}{$\begin{array}{l}\text { Myenteric } \\
\text { plexus }\end{array}$} & \multicolumn{2}{|c|}{$\begin{array}{l}\text { Smooth } \\
\text { muscle }\end{array}$} & \multicolumn{2}{|c|}{$\begin{array}{l}\text { Mucosat } \\
\text { submucosat } \\
\text { submucosal } \\
\text { plexus }\end{array}$} & \multicolumn{2}{|c|}{$\begin{array}{l}\text { Myenteric } \\
\text { plexus }\end{array}$} & \multicolumn{2}{|c|}{$\begin{array}{l}\text { Smooth } \\
\text { muscle }\end{array}$} \\
\hline & $C D$ & $\begin{array}{l}\text { Con- } \\
\text { trols }\end{array}$ & $C D$ & $\begin{array}{l}\text { Con- } \\
\text { trols }\end{array}$ & $C D$ & $\begin{array}{l}\text { Con- } \\
\text { trols }\end{array}$ & $C D$ & $\begin{array}{l}\text { Con- } \\
\text { trols }\end{array}$ & $C D$ & $\begin{array}{l}\text { Con- } \\
\text { trols }\end{array}$ & $C D$ & $\begin{array}{l}\text { Con- } \\
\text { trols }\end{array}$ \\
\hline & \multicolumn{2}{|c|}{ A/NA } & \multicolumn{2}{|c|}{ A/NA } & \multicolumn{2}{|c|}{ A/NA } & \multicolumn{2}{|c|}{$\mathbf{A} / \mathbf{N A}$} & \multicolumn{2}{|c|}{$\mathbf{A} / \mathbf{N A}$} & \multicolumn{2}{|c|}{ A/NA } \\
\hline VIP & $\ddagger / \ddagger$ & $\ddagger$ & $\ddagger / \ddagger$ & $\ddagger$ & $\ddagger / \uparrow$ & $\ddagger$ & $\dagger / \ddagger$ & $\ddagger$ & $\ddagger / \ddagger$ & $\ddagger$ & $\dagger / \ddagger$ & $\ddagger$ \\
\hline SP & $\dagger / t$ & $\dagger$ & $\dagger / \dagger$ & $\dagger$ & $t / t$ & $\dagger$ & $* / *$ & $*$ & $* / *$ & $*$ & & \\
\hline Enk & - & - & $\dagger / \dagger$ & $\dagger$ & $\dagger / \ddagger$ & $\dagger$ & - & - & $\dagger / t$ & $\dagger$ & $\dagger / t$ & $\dagger$ \\
\hline
\end{tabular}

$A=$ afflicted tissue; $\mathbf{N A}=$ non-afflicted tissue. ${ }^{*}$ Rare. $\dagger$ Moderate in number. $\ddagger$ Numerous. 
Table 6 Proportion of $C D$ patients and control patients displaying a predominance of delicate, medium, or coarse nerve fibres. Significant differences in bold type

\begin{tabular}{|c|c|c|c|c|c|c|c|c|c|c|c|c|}
\hline \multirow{4}{*}{$\begin{array}{l}\text { Nerves } \\
\text { containing }\end{array}$} & \multicolumn{6}{|l|}{ Ileum } & \multicolumn{6}{|c|}{ Colon } \\
\hline & \multicolumn{3}{|c|}{ Mucosa+submucosa } & \multicolumn{3}{|c|}{ Smooth muscle } & \multicolumn{3}{|c|}{ Mucosa+submucosa } & \multicolumn{3}{|c|}{ Smooth muscle } \\
\hline & \multicolumn{2}{|l|}{$C D$} & \multirow[b]{2}{*}{ Controls } & \multicolumn{2}{|l|}{$C D$} & \multirow[b]{2}{*}{ Controls } & \multicolumn{2}{|l|}{$C D$} & \multirow[b]{2}{*}{ Controls } & \multicolumn{2}{|l|}{$C D$} & \multirow[b]{2}{*}{ Controls } \\
\hline & $A$ & $N A$ & & $\boldsymbol{A}$ & $N A$ & & $\boldsymbol{A}$ & $N A$ & & $\boldsymbol{A}$ & $N A$ & \\
\hline \multicolumn{13}{|l|}{ VIP } \\
\hline Delicate & $9 / 19$ & $11 / 14$ & $10 / 13$ & $16 / 19^{*}$ & $13 / 14^{*}$ & $5 / 11$ & $8 / 12$ & $8 / 12$ & $14 / 15$ & $6 / 12$ & $4 / 7$ & $11 / 15$ \\
\hline Medium & $1 / 19$ & & $2 / 13$ & $1 / 19$ & & $4 / 11$ & & & & $1 / 12$ & $1 / 7$ & $3 / 15$ \\
\hline Coarse & 9/19* & $3 / 14$ & $1 / 13$ & $2 / 19$ & $1 / 14$ & $2 / 11$ & $4 / 12$ & $4 / 12$ & $1 / 15$ & $5 / 12^{*}$ & $2 / 7$ & $1 / 15$ \\
\hline \multicolumn{13}{|l|}{ SP } \\
\hline Delicate & $9 / 17$ & $10 / 14$ & $11 / 13$ & $10 / 16$ & $9 / 13$ & $9 / 10$ & $8 / 11$ & $8 / 12$ & $11 / 13$ & $8 / 12$ & $7 / 12$ & $11 / 12$ \\
\hline Medium & $2 / 17$ & & $2 / 13$ & & $1 / 13$ & $1 / 10$ & & $2 / 12$ & $2 / 13$ & & $1 / 12$ & $1 / 12$ \\
\hline Coarse & $6 / 17^{*}$ & $4 / 14$ & & $6 / 16^{*}$ & $3 / 13$ & & $3 / 11$ & $2 / 12$ & & $4 / 12$ & $4 / 12$ & \\
\hline \multicolumn{13}{|l|}{ Enk } \\
\hline Delicate & & & & $7 / 14$ & $6 / 14$ & $11 / 13$ & & & & $6 / 10$ & $5 / 10$ & $10 / 15$ \\
\hline Medium & & & & $1 / 14$ & $2 / 14$ & $2 / 13$ & & & & $2 / 10$ & $3 / 10$ & $3 / 15$ \\
\hline Coarse & & & & $6 / 14 \dagger$ & $6 / 14 \dagger$ & & & & & $2 / 10$ & $2 / 10$ & $2 / 15$ \\
\hline
\end{tabular}

$A=$ afflicted tissue $; \mathrm{NA}=$ non-afflicted tissue. ${ }^{*} \mathrm{p}<0.05 .+\mathrm{p}=0.01$
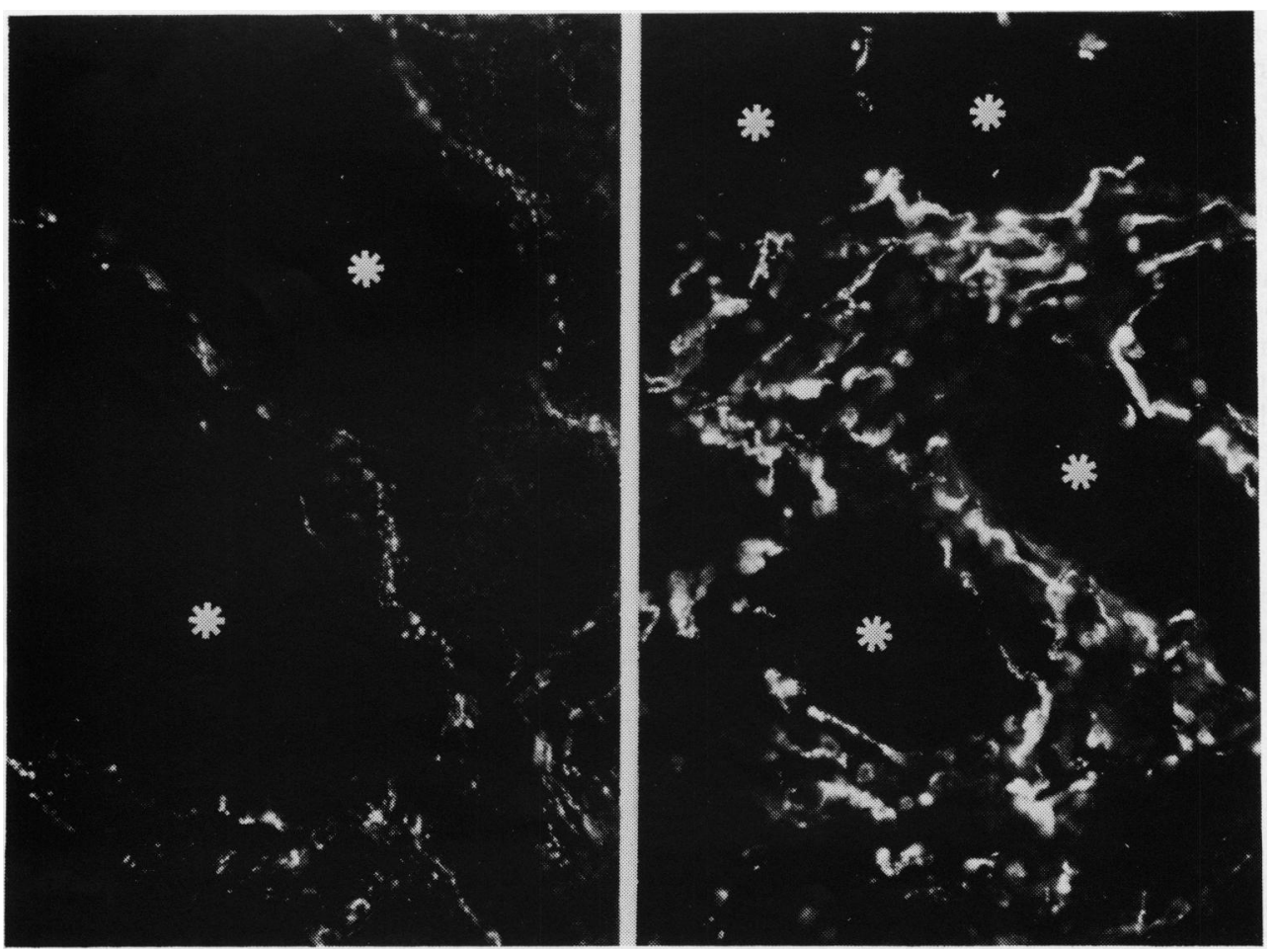

Fig. 1 Ileum mucosa, oblique sections. Rich supply of nerve fibres containing vasoactive intestinal popypeptide (VIP) in normal mucosa (left) and in afflicted mucosa from a Crohn's disease patient (right). The fibres are seen to surround the crypts (asterisks). Note the coarseness of the nerve fibres in Crohn's disease. Cryostat sections of formalin-fixed specimens. Immunofluorescence $(\times 300$, original magnification). 

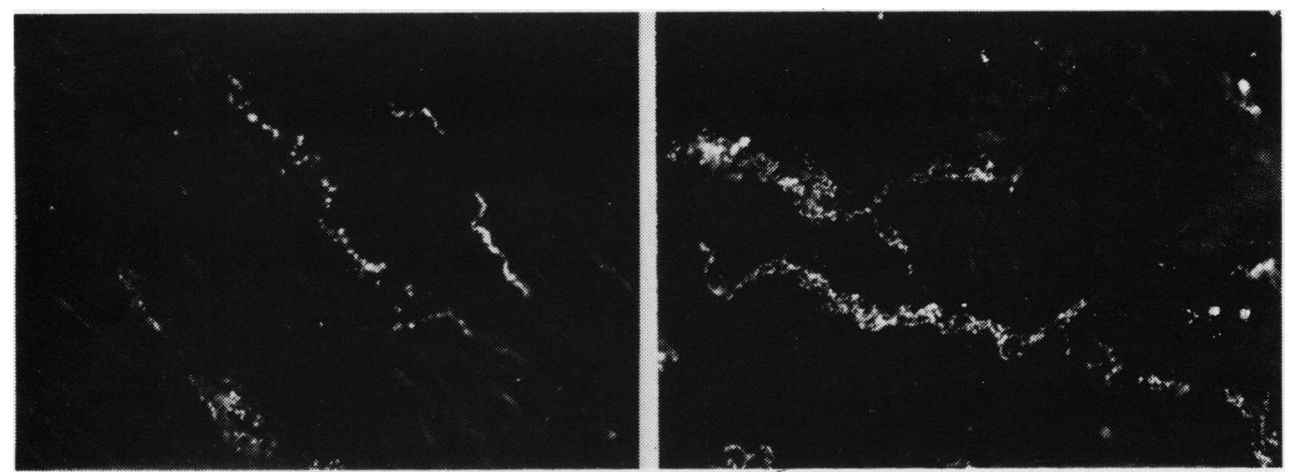

Fig. 2 Ileum smooth muscle. Moderate number of substance $P(S P)$ containing nerve fibres in a control patient (left) and in a patient with Crohn's disease (right). Note coarse nerve fibres in the afflicted smooth muscle in Crohn's disease. Cryostat sections of formalin-fixed specimens. Immunofluorescence $(\times 150$, original magnification).

Crohn's disease and control patients was assessed by Student's $t$ test. Differences in nerve fibre morphology were assessed by $\chi^{2}$ analysis or if one group consisted of fewer than five patients by Fischer's exact test. Statistical significance of the results of radioimmunochemical analysis was assessed by non-parametric one-way analysis of

variance (Kruskal-Wallis) and by Wilcoxon's rank test.

\section{Results}

IMMUNOCYTOCHEMICAL OBSERVATIONS

Endocrine cells The number of 5-hydroxy-
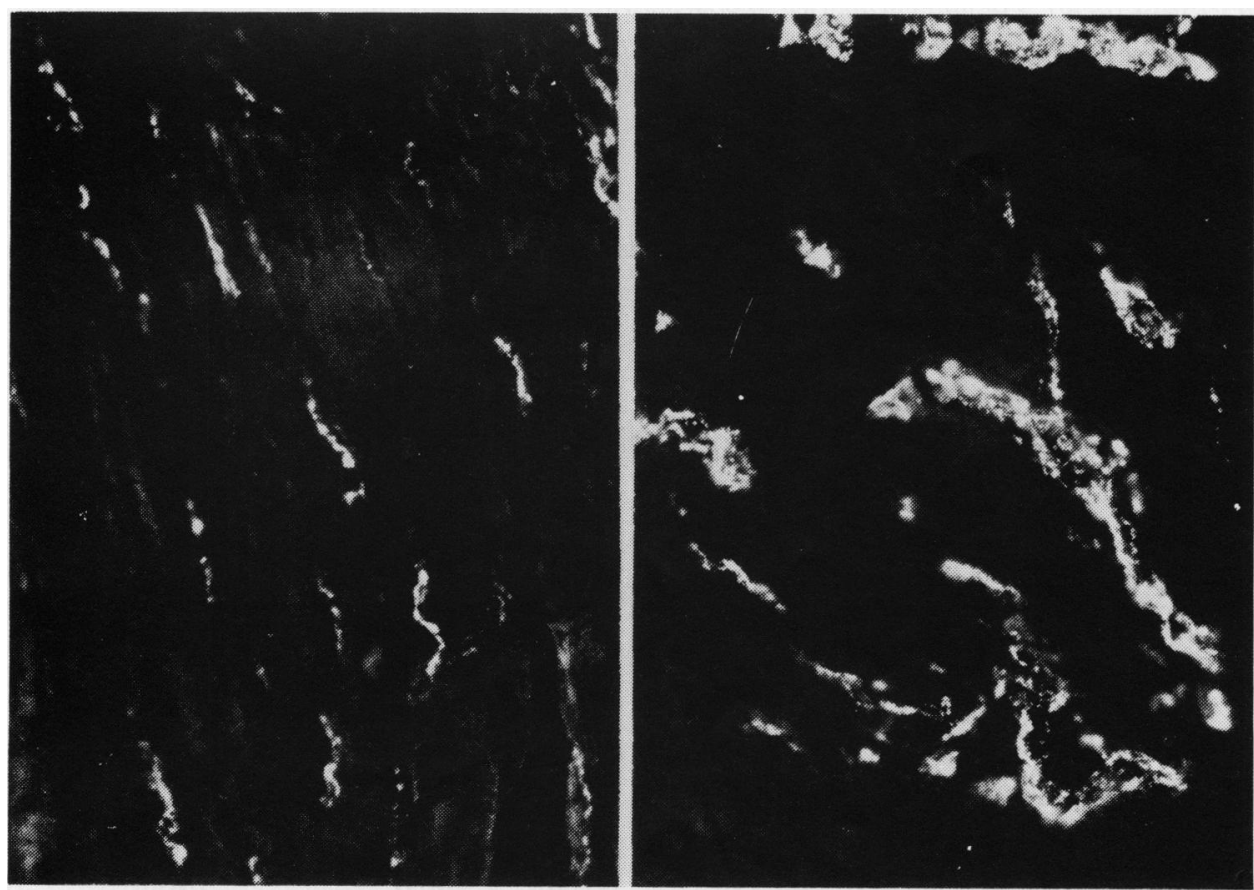

Fig. 3 Ileum smooth muscle. Control patient (left) and Crohn's disease (right). Marked thickening of enkephalinimmunoreactive nerve fibres in afflicted smooth muscle in Crohn's disease. Cryostat sections of formalin-fixed specimens. Immunofluorescence $(\times 200$, original magnification). 

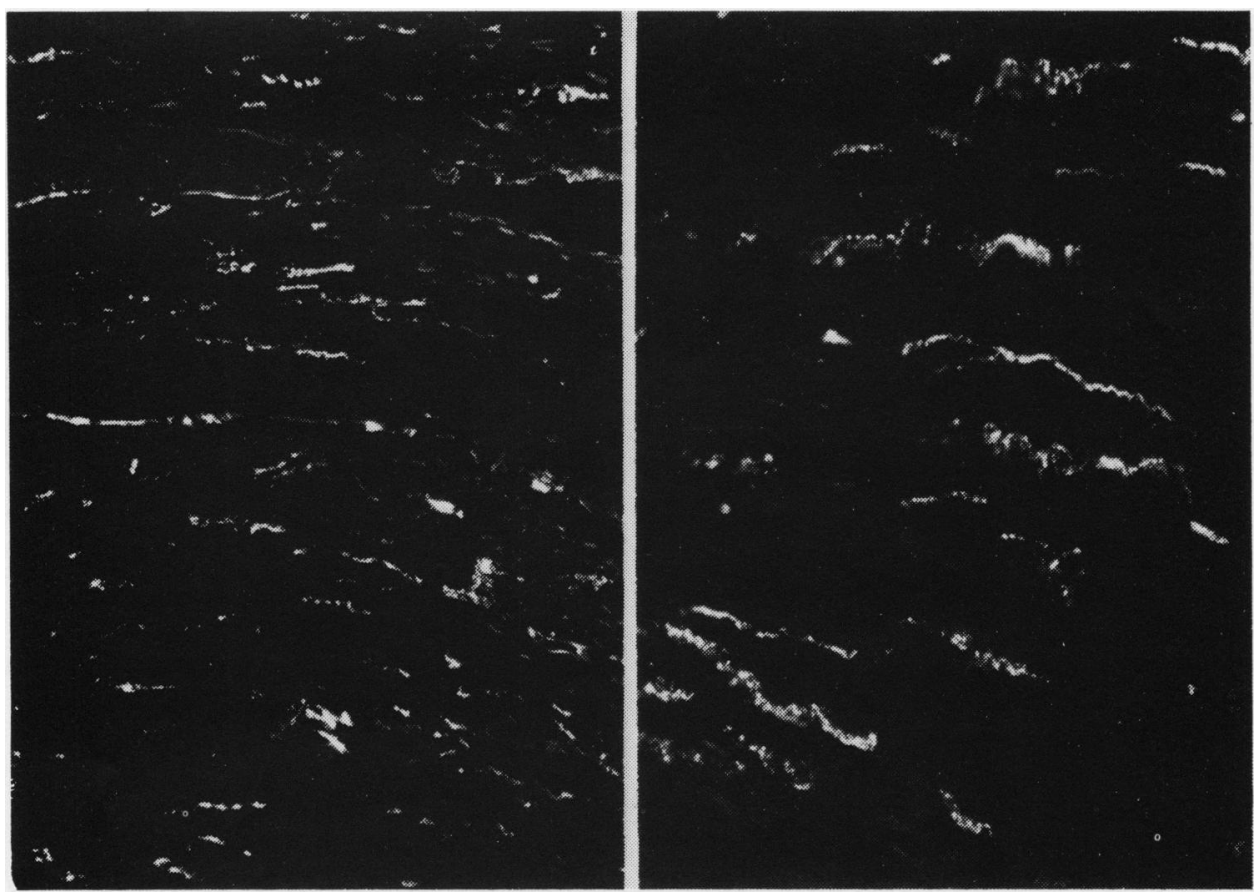

Fig. 4 Colon smooth muscle. VIP-immunoreactive nerve fibres in smooth muscle from â control patient (left) and a patient with Crohn's disease (right). VIP fibres in afflicted smooth muscle are only slightly more coarse than in the control specimen. Cryostat sections of formalin-fixed specimens. Immunofluorescence ( $\times 150$, original magnification).

tryptamine-containing enterochromaffin cells, glucagon/glicentin cells, neurotensin cells, somatostatin cells, gastrin/CCK cells, and substance $P$ cells in the ileum of Crohn's disease patients did not differ significantly from that in the controls. Also the number of endocrine cells in the colon (enterochromaffin cells, glucagon/glicentin, and somatostatin cells) was unaltered (Table 4). It cannot be excluded that the influence of focal inflammation with consequent enlargement of the lamina propria may have affected the results of cell counting. The tissue specimens included in this analysis were taken from several different parts of the afflicted intestine as well as from non-afflicted parts. There was no significant difference in cell counts between afflicted and non-afflicted intestine.

Peptide-containing nerve fibres Vasoactive intestinal polypeptide immunoreactive nerve fibres were numerous in all layers of the intestinal wall. Intensely stained nerve cell bodies were regularly

Table 7 Concentration of VIP in ileum and colon

\begin{tabular}{|c|c|c|c|c|c|c|}
\hline \multirow[b]{3}{*}{ Location } & \multicolumn{4}{|c|}{ Crohn's disease } & & \\
\hline & \multicolumn{2}{|l|}{$N A$} & \multicolumn{2}{|l|}{$\boldsymbol{A}$} & \multicolumn{2}{|l|}{ Controls } \\
\hline & $\begin{array}{l}\text { pmollg } \\
\text { wet weight }\end{array}$ & $\begin{array}{l}\text { pmollg } \\
\text { protein }\end{array}$ & $\begin{array}{l}\text { pmollg } \\
\text { wet weight }\end{array}$ & $\begin{array}{l}\text { pmollg } \\
\text { protein }\end{array}$ & $\begin{array}{l}\text { pmollg } \\
\text { wet weight }\end{array}$ & $\begin{array}{l}\text { pmollg } \\
\text { protein }\end{array}$ \\
\hline $\begin{array}{l}\text { Ileum mucosa } \\
\text { Ileum smooth muscle } \\
\text { Colon mucosa } \\
\text { Colon smooth muscle }\end{array}$ & $\begin{array}{l}263(9) \\
284(8) \\
356(8) \\
206(7)\end{array}$ & $\begin{array}{l}20(9) \\
53(8) \\
30(8) \\
36(7)\end{array}$ & $\begin{array}{l}247(7) \\
110(7) \\
49(5) \dagger \ddagger \\
89(4)^{*}\end{array}$ & $\begin{array}{l}23(7) \\
29(7) \\
10(4) \\
14(4)\end{array}$ & $\begin{array}{l}160(6) \\
253(5) \\
288(8) \\
217(6)\end{array}$ & $\begin{array}{l}20(6) \\
37(5) \\
25(8) \\
35(6)\end{array}$ \\
\hline
\end{tabular}

$\mathrm{NA}=$ non-afflicted tissue; $\mathrm{A}=$ afflicted tissue. ${ }^{*} \mathrm{p}<0.05 ; \mathrm{p}<0.01$ compared with control group; $\ddagger \mathrm{p}<0.01$ compared with non-afflicted specimens. 
Table 8 Concentration of substance $P$ in ileum and colon

\begin{tabular}{|c|c|c|c|c|c|c|}
\hline \multirow[b]{3}{*}{ Location } & \multicolumn{4}{|c|}{ Crohn's disease } & & \\
\hline & \multicolumn{2}{|l|}{$N A$} & \multicolumn{2}{|l|}{$A$} & \multicolumn{2}{|l|}{ Controls } \\
\hline & $\begin{array}{l}\text { pmol/g } \\
\text { wet weight }\end{array}$ & $\begin{array}{l}\text { pmol/g } \\
\text { protein }\end{array}$ & $\begin{array}{l}\text { pmollg } \\
\text { wet weight }\end{array}$ & $\begin{array}{l}\text { pmol/g } \\
\text { protein }\end{array}$ & $\begin{array}{l}\text { pmol/g } \\
\text { wet weight }\end{array}$ & $\begin{array}{l}\text { pmol/g } \\
\text { protein }\end{array}$ \\
\hline Ileum mucosa & $17 \cdot 4(11)$ & $1 \cdot 1(11)$ & $6 \cdot 3(10)$ & $0.75(10)$ & $9.9(6)$ & $1.20(6)$ \\
\hline Ileum smooth muscle & $9 \cdot 1(11)$ & $1 \cdot 8(11)$ & $4 \cdot 3(10)$ & $1 \cdot 1(10)$ & $6 \cdot 0(6)$ & $0.96(6)$ \\
\hline Colon mucosa & $15 \cdot 1(10)$ & $0.86(10)$ & $3.6(7)^{*}$ & $0.55(7)$ & $8.6(9)$ & $0.74(9)$ \\
\hline Colon smooth muscle & $11 \cdot 6(10)$ & $1 \cdot 1(10)$ & $2 \cdot 1(5)$ & $0.36(5)$ & $3 \cdot 3(7)$ & $0.49(7)$ \\
\hline
\end{tabular}

$\mathrm{NA}=$ non-afflicted tissue; $\mathrm{A}=$ afflicted tissue. ${ }^{*} \mathrm{p}<0.05$ compared with control group.

observed in the submucous and myenteric plexuses. In non-afflicted smooth muscle of the ileum and in the afflicted colon from subjects with Crohn's disease the number of VIP nerves was lower than in the corresponding locations in control patients (Table 5). Coarse VIP nerve fibres were more frequently observed in the afflicted mucosa of the ileum and in the afflicted smooth muscle of the colon than in the corresponding locations in control patients (Table 6; Figs 1, 4).

Substance $\mathbf{P}$ nerve fibres were moderate in number in the ileum and few in the colon. Their frequency was the same in the mucosa as in the smooth muscle. Immunoreactive nerve cell bodies were observed in the submucous and myenteric plexuses in all regions of the intestine. In patients with Crohn's disease the number of substance $P$ fibres did not differ from that in the control group (Table 5). In one third of the Crohn's disease patients a large portion of the substance $P$ nerve fibres was graded as coarse in the ileum; in the control group no coarse nerve fibres were observed (Table 6; Fig. 2).

Enkephalin-containing nerve fibres were more or less restricted to the smooth muscle and the myenteric plexus, where they occurred in a moderate number in the ileum and colon (Table 5). Immunoreactive nerve cell bodies were seen in the myenteric plexus. Such nerve cell bodies were more numerous in the non-afflicted than in the afflicted ileum, and more numerous than in the control group. About half of the Crohn's disease patients had coarse nerve fibres in both non-afflicted and afflicted ileum; none in the control group had coarse fibres (Table 6; Fig. 3).

Peptide-containing nerve fibres in the middle part of the ileum in Crohn's disease patients displayed the same frequency and coarseness as those in the distal part. Specimens from Crohn's disease patients previously subjected to intestinal resection did not contain more coarse nerve fibres than those taken from the unresected group with this disease.
IMMUNOCHEMICAL FINDINGS

The concentration of VIP (expressed per gram wet weight) was markedly reduced in the afflicted colon and in some patients also in the non-afflicted colon. In other locations the VIP concentration did not differ significantly from that of the controls. When the VIP concentration was expressed per gram extracted protein no difference was noted between Crohn's disease patients and controls in any location (Table 7).

In the afflicted colonic mucosa the substance $P$ concentration was reduced when expressed per gram wet weight whereas no significant difference could be observed when the concentrations were expressed per gram extracted protein (Table 8).

The concentration of extractable protein in the gut wall of patients with Crohn's disease did not differ significantly from that in the control group (Table 9).

\section{Discussion}

The present immunocytochemical findings indicate that on the whole intestinal nerve fibres containing VIP, substance $P$, or enkephalin have the same frequency in Crohn's disease patients and in control

Table 9 Concentration of extractable protein in ileum and colon

\begin{tabular}{|c|c|c|c|}
\hline \multirow[b]{2}{*}{ Location } & \multicolumn{2}{|c|}{ Crohn's disease } & \multirow[b]{2}{*}{$\begin{array}{l}\text { Controls } \\
\text { mg/g we } \\
\text { weight }\end{array}$} \\
\hline & $\begin{array}{l}\text { NA } \\
\text { mg/g wet } \\
\text { weight }\end{array}$ & $\begin{array}{l}A \\
\text { mg/g wet } \\
\text { weight }\end{array}$ & \\
\hline \multirow{5}{*}{$\begin{array}{l}\text { Ileum mucosa } \\
\text { Ileum smooth } \\
\text { muscle } \\
\text { Colon mucosa } \\
\text { Colon smooth } \\
\text { muscle }\end{array}$} & $9 \cdot 1(11)$ & $6 \cdot 3(10)$ & $7 \cdot 6(6)$ \\
\hline & $3.4(11)$ & $4 \cdot 0(10)$ & $3.9(6)$ \\
\hline & $8 \cdot 8(10)$ & $3.9(7)$ & $9 \cdot 3(9)$ \\
\hline & & & \\
\hline & $4 \cdot 7(3)$ & $3 \cdot 8(6)$ & $6 \cdot 3(7)$ \\
\hline
\end{tabular}

$\mathrm{NA}=$ non-afflicted tissue; $\mathrm{A}=$ afflicted tissue. 
patients, while being more coarse in Crohn's disease patients. This was particularly apparent in the afflicted parts of the intestine although it was noted also in non-afflicted parts. In the ileum all three types of peptide containing nerve fibres were coarse, whereas in the colon only VIP nerve fibres were coarse. On the whole our morphological findings confirm and extend those of Bishop et al. ${ }^{6}$ These authors, however, reported much higher VIP concentration (expressed as $\mathrm{pmol} / \mathrm{g}$ wet weight) in the intestine of patients with Crohn's disease than in control patients, a finding that we have not been able to confirm. In our study, the concentration of VIP in the intestine of Crohn's disease patients did not exceed that of the control group. On the contrary, the VIP concentration in the afflicted colon was reduced. As Crohn's disease is associated with increased thickness of the bowel wall because of fibrosis and oedema, however, the unchanged VIP and substance $P$ concentrations in the intestine in Crohn's disease patients may correspond to an increased total amount of intestinal VIP and substance $P$. It must be realised that the patients of the present study differ from the patients described by Bishop et at in that the lesions were localised to the ileum rather than to the colon. The two groups of patients may differ also with respect to the severity of the lesions.

Crohn's disease seems to affect several types of peptide containing nerves such as those containing VIP, substance P, or enkephalin. As chemical determinations did not reveal any increase in the intestinal VIP and substance $P$ concentrations compared with the control group the changes are probably less pronounced than suggested from previous observations. ${ }^{6}$

The mechanisms behind the neuromorphological changes in Crohn's disease are obscure. They may be secondary to the intestinal inflammation and fibrosis.

This investigation was supported by grants from 'Förenade Liv' - Mutual Group Life Insurance Company, Stockholm, Sweden; The Swedish Medical Research Council (04X-4499, 04X-1007); Albert Påhlson's Foundation, Malmö, Sweden; and Smith, Kline and French AB, Stockholm, Sweden.

\section{References}

1 De Dombal FT. Definition of Crohn's disease. In: Pena AS, Weterman IT, Booth CC, Strober W, eds. Recent advances in Crohn's disease. Developments in gastroenterology 1981; 1: 3-6.

2 Goldberg HI, Caruthers SB, Nelson JA, Singleton JW.
Radiographic findings of national cooperative Crohn's disease study. Gastroenterology 1979; 77: 925-37.

3 Mekhjian HS, Switz DM, Melnyk CS, Rankin GB, Brooks RK. Clinical features and natural history of Crohn's disease. Gastroenterology 1979; 77: 898-906.

4 Whitehead R. Pathology of Crohn's disease of the colon. In: Kirsner JB, Shorter RG, eds. Inflammatory bowel disease. Philadelphia: Lea and Febiger, 1975: $182-98$.

5 Morson BC. Regional enteritis (Crohn's disease). Part I: pathology. In: Bockus HL, ed. Gastroenterology, 3rd ed. London: W B Saunders, 1976: 550-61.

6 Bishop AE, Polak JM, Bryant MG, Bloom SR, Hamilton S. Abnormalities of vasoactive intestinal polypeptide containing nerves in Crohn's disease. Gastroenterology 1980; 79: 853-60.

7 Mee AS, Brown DJ, Jewell DP. Crohn's disease activity index - is it useful? (Abstract). Gut 1978; 19: 990.

8 Pearse AGE, Polak JM. Bifunctional reagents as vapour- and liquid phase fixatives for immunohistochemistry. Histochemistry 1975; 71: 179-86.

9 Björklund A, Falck B, Owman C. Fluorescence microscopic and microspectrofluorometric techniques for the cellular localization and characterization of biogenic amines. In: Rall JE, Kopin IJ, eds. Methods in investigative and diagnostic endocrinology. Amsterdam: North Holland, 1972: 318-68.

10 Sternberger LA. Immunocytochemistry. 2nd ed. New York, Toronto: John Wiley, 1979.

11 Coons AH, Leduc EH, Conolly JM. Studies of antibody production. I. A method for the histochemical demonstration of specific antibody and its application to a study of the hyperimmune rabbit. J Exp Med 1955; 102: 49-60.

12 Lowry OH, Rosenbrough NJ, Farr RJ, Randall RL. Protein measurement with the Folin phenol reagent. $J$ Biol Chem 1951; 193: 265-75.

13 Brodin E, Nilsson G, Folkers K. Characterization of two substance P antisera. Acta Physiol Scand 1982; 114: 53-7.

14 Hunter WM, Greenwood FC. Preparation of iodine131 labelled human growth hormone of high specific activity. Nature 1962; 194: 495.

15 Brodin $\mathrm{E}$, Sjölund $\mathrm{K}$, Håkanson $\mathrm{R}$, Sundler $\mathrm{F}$. Substance $P$ containing nerve fibers are numerous in human but not in feline intestinal mucosa. Gastroenterology 1983. (In press).

16 Fahrenkrug J, Schaffalitzky de Muckadell OB. Radioimmunoassay of vasoactive intestinal polypeptide (VIP) in plasma. J Lab Clin Med 1977; 89: 1379-87.

17 Lorén I, Alumets J, Håkanson R, Sundler F. Distribution of gastrin and CCK-like peptides in rat brain. An immunocytochemical study. Histochemistry 1979; 59: $249-57$.

18 Sjölund K, Ekelund M, Håkanson R, Moody AJ, Sundler F. GIP-like immunoreactivity in glucagon and glicentin cells. Properties and origin. An immunocytochemical study using several GIP antisera. $J$ Histochem Cytochem 1983; 31.

19 Alumets J, Sundler F, Chang KJ. Leu-enkephalin-like material in nerves and enterochromaffin cells in the 
gut. Histochemistry 1978; 56: 187-96.

20 Carraway R, Leeman SE. Radioimmunoassay of neurotensin, a hypothalamic peptide. J Biol Chem 1976; 251: 7035-44.

21 Dubois MP. Immunoreactive somatostatin is present in discrete cells of the endocrine pancreas. Proc Natl Acad Sci 1975; 72: 1340-3.

22 Brodin $\mathrm{E}$, Alumets $\mathrm{G}$, Håkanson $\mathrm{R}$, Leander $\mathrm{S}$, Sundler $F$. Immunoreactive substance $P$ in chicken gut: distribution, development and possible functional significance. Cell Tiss Res 1981; 216: 455-69.

23 Alm P, Alumets J, Håkanson R, Owman C, Sjöberg NO, Sundler F, Walles B. Origin and distribution of VIP (vasoactive intestinal polypeptide) - nerves in the. genito-urinary tract. Cell Tiss Res 1980; 205: 337-47.

24 Steinbusch HWM, Verhofstad AAJ, Joosten HW. Localization of serotonin in the central nervous system by immunohistochemistry: description of a specific and sensitive technique and some applications. Neuroscience 1978; 3: 811-9. 